\title{
Modeling the effects of neuronal morphology on dendritic chloride diffusion and GABAergic inhibition
}

\author{
Namrata Mohapatra ${ }^{1 *}$, Fidel Santamaria $^{2}$, Peter Jedlicka ${ }^{1}$ \\ From The Twenty Third Annual Computational Neuroscience Meeting: CNS*2014 \\ Québec City, Canada. 26-31 July 2014
}

Gamma-aminobutyric acid receptors $\left(\mathrm{GABA}_{\mathrm{A}} \mathrm{Rs}\right)$ are ligand-gated chloride $\left(\mathrm{Cl}^{-}\right)$channels which mediate the majority of inhibitory neurotransmission in the CNS. Spatiotemporal changes of intracellular $\mathrm{Cl}^{-}$concentration alter the concentration gradient for $\mathrm{Cl}^{-}$across the neuronal membrane and thus affect the current flow through $\mathrm{GABA}_{\mathrm{A}}$ Rs and the efficacy of GABAergic inhibition. However, the impact of complex neuronal morphology on $\mathrm{Cl}^{-}$diffusion and the redistribution of intracellular $\mathrm{Cl}$ - is not well understood. Recently, computational models for $\mathrm{Cl}^{-}$diffusion and $\mathrm{GABA}_{\mathrm{A}} \mathrm{R}$-mediated inhibition in realistic neuronal morphologies became available [1-3]. Here we have used computational models of morphologically complex dendrites to test the effects of spines on $\mathrm{Cl}$ - diffusion. In all dendritic morphologies tested, spines slowed down longitudinal $\mathrm{Cl}^{-}$diffusion along dendrites and decreased the amount and spatial spread of synaptically evoked $\mathrm{Cl}^{-}$changes. Spine densities of 2-10 spines/ $\mu \mathrm{m}$ decreased the longitudinal diffusion coefficient of $\mathrm{Cl}^{-}$ to $80-30 \%$ of its value in smooth dendrites, respectively. These results suggest that spines are able to limit shortterm ionic plasticity [4] at dendritic GABAergic synapses.

\section{Acknowledgements \\ Supported by the NSF/BMBF (US-German Collaboration in Computational Neuroscience, No. 01GQ1203A).}

\section{Authors' details}

'Institute of Clinical Neuroanatomy, Neuroscience Center, Goethe-University,

Frankfurt, Germany. ${ }^{2}$ Biology Department and Neurosciences Institute, The

University of Texas at San Antonio, San Antonio, USA.

Published: 21 July 2014

\footnotetext{
* Correspondence: mohapatra@em.uni-frankfurt.de

'Institute of Clinical Neuroanatomy, Neuroscience Center, Goethe-University, Frankfurt, Germany
}

Full list of author information is available at the end of the article

\section{References}

1. Jedlicka P, Deller T, Gutkin BS, Backus KH: Activity-dependent intracellular chloride accumulation and diffusion controls $G A B A_{A}$ receptor-mediated synaptic transmission. Hippocampus 2011, 21:885-898.

2. Doyon N, Prescott SA, Castonguay A, Godin AG, Kröger H, Koninck YD: Efficacy of synaptic inhibition depends on multiple, dynamically interacting mechanisms implicated in chloride homeostasis. PLOS Comput Biol 2011, 7(9):e1002149.

3. Lewin N, Aksay E, Clancy CE: Computational modeling reveals dendritic origins of $\mathrm{GABA}_{\mathrm{A}}$-mediated excitation in CA1 pyramidal neurons. PLOS One 2012, 7(10):e47250.

4. Raimondo JV, Markram H, Akerman CJ: Short-term ionic plasticity at GABAergic synapses. Front Syn Neurosci 2012, 4:5.

\section{doi:10.1186/1471-2202-15-S1-P138}

Cite this article as: Mohapatra et al:: Modeling the effects of neuronal morphology on dendritic chloride diffusion and GABAergic inhibition. BMC Neuroscience 2014 15(Suppl 1):P138.
Submit your next manuscript to BioMed Central and take full advantage of:

- Convenient online submission

- Thorough peer review

- No space constraints or color figure charges

- Immediate publication on acceptance

- Inclusion in PubMed, CAS, Scopus and Google Scholar

- Research which is freely available for redistribution
() Biomed Central 